University of Wollongong

Research Online

Faculty of Law, Humanities and the Arts Papers (Archive)

$1-1-2018$

Constraints preventing Chinese EFL teachers from putting their stated beliefs into teaching practice

\author{
Lei-Min Shi \\ University of Wollongong, Ishi@uow.edu.au \\ Janine Delahunty \\ University of Wollongong, janined@uow.edu.au \\ Xiaoping Gao \\ University of Wollongong, xiaoping@uow.edu.au
}

Follow this and additional works at: https://ro.uow.edu.au/lhapapers

Part of the Arts and Humanities Commons, and the Law Commons

Research Online is the open access institutional repository for the University of Wollongong. For further information contact the UOW Library: research-pubs@uow.edu.au 


\title{
Constraints preventing Chinese EFL teachers from putting their stated beliefs into teaching practice
}

\begin{abstract}
In China, developing students' overall communicative competence was set as the central goal of the current college English curriculum requirements since 2004. However, this goal has remained largely unfulfilled, particularly with regard to writing competence. This study proposes that the genrebased pedagogy in systemic functional linguistics may be the key to achieve this national curriculum goal. After teachers were trained in this pedagogy, through designed workshops for teacher development, this research examined possible changes in teachers' stated beliefs about effective writing pedagogy and actual teaching practices. The findings from classroom observations and teachers' self-reports suggest that even though all teacher participants valued the genre-based pedagogy, a very weak connection was made to their actual teaching practice. This study aimed to understand possible constraints leading to this inconsistency. Teachers' prior instructional knowledge, general attitudes to educational changes, selfconfidence, and contextual factors such as class size, knowledge of students and assessment, were the main contributors to inconsistency. To overcome barriers and maximize the effectiveness of the genrebased pedagogy in achieving the national curriculum goal, several implications are discussed.
\end{abstract}

\section{Keywords}

constraints, practice, preventing, chinese, efl, teachers, putting, their, stated, beliefs, into, teaching

\section{Disciplines}

Arts and Humanities | Law

\section{Publication Details}

Shi, L., Delahunty, J. \& Gao, X. (2019). Constraints preventing Chinese EFL teachers from putting their stated beliefs into teaching practice. Professional development in education, 45 (5), 774-789. 


\title{
Constraints preventing Chinese EFL teachers from putting their stated beliefs into teaching practice
}

\author{
Dr. Leimin Shi
}

Faculty of Law, Humanities and the Arts, University of Wollongong

Northfields Ave Wollongong NSW 2522 Australia

Telephone: 61242213066 Email: 1shi@uow.edu.au

ORCID identifiers: 0000000271671210

Dr Janine Delahunty

Department of Teaching \& Curriculum Development, University of Wollongong

Northfields Ave Wollongong NSW 2522 Australia

Telephone: 61242213396 janined@uow.edu.au

Dr Xiaoping Gao

Faculty of Law, Humanities and the Arts, University of Wollongong

Northfields Ave Wollongong NSW 2522 Australia

Telephone: 61242215270 xiaoping@ uow.edu.au 


\title{
Constraints preventing Chinese EFL teachers from putting their stated beliefs into teaching practice
}

\begin{abstract}
In China, developing students' overall communicative competence was set as the central goal of the current College English curriculum requirements since 2004. However, this goal has remained largely unfulfilled, particularly with regard to writing competence. This study proposes that the genre-based pedagogy in Systemic Functional Linguistics may be the key to achieve this national curriculum goal. After teachers were trained in this pedagogy, through designed workshops for teacher development, this research examined possible changes in teachers' stated beliefs about effective writing pedagogy and actual teaching practices. The findings from classroom observations and teachers' self-reports suggest that even though all teacher participants valued the genre-based pedagogy, a very weak connection was made to their actual teaching practice. This study aimed to understand possible constraints leading to this inconsistency. Teachers' prior instructional knowledge, general attitudes to educational changes, self-confidence, and contextual factors such as class size, knowledge of students and assessment, were the main contributors to inconsistency. To overcome barriers and maximize the effectiveness of the genre-based pedagogy in achieving the national curriculum goal, several implications are discussed.
\end{abstract}

Key words: Belief; genre pedagogy; communicative language teaching; writing; consistency

\section{Introduction}

In China, developing students' overall communicative competence, in line with communicative language teaching (CLT) approach, is the mandate of College English (CE) Curriculum Requirements (CECR) 2004 national reform goal. Hence developing students' overall language competencies in appropriate language use (listening, speaking, reading and writing) in social and cultural contexts (Hymes 1972) is paramount.

Most researchers agree that the application of CLT in China has been a failure for several reasons. First, English teaching in China is described as being teacher-centred, which contradicts the student-centred teaching approach of CLT. As a result, inadequate classroom interactions become a major obstacle in developing students' communicative competence (Fang 2010). Similarly, large class sizes are commonly cited as an obstacle restricting the adoption of the learner-centred teaching style (Siemon 2010, Yü 2001) which limits students' interactional opportunities. In addition, there are no sufficient instructions in the CECR on how to develop students' communicative competence (Gao and Huang 2010). Also, the teaching of writing is driven by the national assessment system, the 
College English Test (CET), which has been criticized for reflecting an ingrained traditional focus on accuracy in language use (Fang 2010) regardless of the more complex and broader demands added on students' writing ability when updating the CECR in 1999.

\section{Genre approach in EFL contexts worldwide}

There is a significant body of literature in the area of teaching English writing as a foreign language (EFL). The genre approach in Systemic Functional Linguistic (SFL) has become one of the most popular. The instructional model of this approach is the teaching-learning cycle comprising three processes of Modelling, Joint Negotiation of Text, and Independent Construction of Text (Callaghan and Rothery 1988). The Modelling stage includes exposing students to models of target genre to develop familiarity (Feez 1999). In the stage of Joint Negotiation of Text, students are invited to collaboratively construct a new text of the same genre through various interaction activities. Once their control of the genre is developed, students produce a new text independently in the Independent Construction stage. Underpinning this cycle is the Vygotskian socio-cultural theory and the associated notion of scaffolding - that learning is through guidance and interaction in the context of shared experience (Martin 1999). Scaffolding refers to the assistance provided by a more capable person when a task is beyond a learner's capacity (Wells 1999). Integrating all four language skills to achieve communicative purposes is a major consideration in the SFL genre approach (Derewianka 1990).

The benefits of SFL genre pedagogy in EFL educational contexts worldwide are well demonstrated in the literature (Chaisiri 2010 in Thailand, Cheng 2008 in Taiwan, Emilia 2005 in Indonesia). For example, Lin (2006) reported very positive feedback from a third-year writing program in a Japanese university. Students felt strongly that they benefited from modelling of texts and learning grammatical features in particular, while the teachers believed that the students had made visible progress in their final products by engaging in various tasks and activities. In an Indonesian tertiary level context, Emilia's (2005) case study revealed that adopting the genre approach in her 11week program was most significantly successful in achieving enhanced control of the target Argumentative Genre.

Investigations can also be found in Chinese contexts and many researchers advocate the SFL genre approach (e.g. Deng et al. 2014, Hu 2007, Qian 2010). These studies are mainly conceptual but several empirical ones are worth noting. Tian (2010) employed a web-based server software platform in a tertiary context for the purpose of developing online courses, with procedures for implementing the teaching-learning cycle to teach the Narrative Genre suggested. In Wang's (2013) mixed-methods study, two classes of CE students participated in an optional course to learn practical English writing 
using genre pedagogy. This was beneficial for enhancing students' genre awareness, integral writing quality and lexical density. In a recent paper, Shi et al (2017) discussed Chinese EFL teachers' cognition of the effectiveness of SFL genre pedagogy. By comparing pre- and post- workshop interview and observation findings, it was suggested that teachers particularly valued the pedagogy in developing students' knowledge about text format, language features and argument ideas. To extend this discussion, the current study investigates the gap between teachers' statements about the pedagogy and their actual teaching practices, and the causes leading to inconsistency.

Additionally, similarities that SFL genre pedagogy shares with the CLT approach highlight the value of introducing it to achieve the CECR mandate. Both approaches concern appropriate communication and emphasize classroom interactions. While adopting small group activities is one typical characteristic of CLT (Cai 2008), group work is also frequently used in genre pedagogy (Hyland 2007). SFL genre approach fits well with CLT as 'it provides teachers and learners with a means of exploring language use within a framework of cultural and social purpose' (Burns 2001, p. 200).

\section{Professional development and teacher cognition in educational changes}

It is generally agreed that professional development refers to any activity, which can effectively increase teacher learning, change their practice, and ultimately improve students' learning outcomes, although research foci vary in terms of evaluating its effects on teachers and students. Guskey (2002) provided a model showing significant changes in teachers' beliefs would not occur until students' improvements are evidenced. Such improvements occur when teachers apply new instructional approaches. However, it is not necessarily the professional development itself, but teachers' experience of successful implementation that changes their beliefs. Instead of emphasizing the orders of the change occurrences, Desimone's (2009) framework of evaluating professional development highlights the relationship between the changes in teacher learning, teaching practice and students' learning outcomes are reciprocal. In particular, contextual factors like teacher and student characteristic, curriculum, and so on, are pointed out as important mediating and moderating influences on professional development.

Researchers have investigated relationships between elements of teacher learning, changes in practice, and student outcomes. Focusing on opportunities and resources for motivating teachers' professional development, Durksen et al. (2017) found that teachers' efficacy beliefs predict their engagement and positive beliefs about professional learning, and that they prefer collective study with colleagues. This demonstrates that professional development can happen through many different 
aspects of practice (Borko, 2004), rather than waiting until successful implementation is experienced and/or students' learning outcomes are achieved. Kang and Cheng (2014) report in their case study that the development of teacher cognition (TC) of language teaching content and pedagogy can result from cyclical interactions in classroom practices. In a mixed-method research conducted in Iran, Jamalzadeh and Shahsavar (2015) reveal that teaching context does not affect teacher belief and practice. Having similar interest in the impact of contextual factors, the current research explores the constraints that may prevent teachers from implementing their perceived beliefs into teaching practice.

The term TC is defined as 'what teachers know, believe and think' (Borg 2003, p. 81) and concerns how teachers' beliefs and knowledge guide their classroom teaching behaviours. The implementation of any educational innovation requires adjustments and improvements in at least three components: materials, teaching approaches and beliefs (Fullan 2001). Only when changes occur in all three components can a particular educational goal possibly be achieved. Teachers' understanding and belief is the foundation of any innovation success (Priestley 2011). Conversely, mismatches between the main principles underlying curriculum and teachers' beliefs are likely to become the most crucial obstacles when implementing educational innovations. While a substantial body of work on TC in ESL teaching over the last three decades can also be found (Borg, 2003), the argument for consistency between teachers' stated beliefs and their classroom behaviours (Kim 2006, Yang and Gao 2013) is frustrated by greater evidence of inconsistencies (Farrell and Lim 2005, Hedrick et al 2004, Khader 2012). In China, increasing research on TC and its significant impact on teachers' classroom practices also with particular discussion on influential factors impacting consistency levels. Zhang (2011) reports that teaching practices are strongly influenced by various components of TC including teachers' personality, knowledge of teaching, and choices of teaching approaches based on teacher-student relationship and teachers' understanding of students. In an investigation of teachers' beliefs in a national curricular innovation, Zheng and Borg (2014) argue that apart from understanding the new pedagogy, teachers' implementation of pedagogical change is largely influenced by existing pedagogical beliefs and contextual factors, which is also echoed in Zhang and Liu's (2013) study.

As discussed, there is increasing literature on SFL genre approach and TC in Chinese contexts. However, none to date, has examined the consistency level between teachers' stated beliefs about a new western writing pedagogy and their actual teaching practices, nor the factors leading to such (in)consistency. Meanwhile, the increasing number of Chinese teachers who have studied in western countries for TESOL (Teaching English to Speakers of Other Languages) or other teacher 
education programs (Bei 2015), are more likely to apply western pedagogies. However the value of professional development in improving teacher instruction is often overlooked. Thus, based on teachers' experiences of the training in SFL genre pedagogy, as a professional development program, this paper explores what may hinder Chinese EFL teachers from putting their stated beliefs into teaching practice, by addressing the following research questions:

(1) How do Chinese EFL teachers make sense of SFL genre pedagogy to support students' learning of writing?

(2) What do Chinese EFL teachers actually do when implementing SFL genre pedagogy in their teaching practice?

(3) What may prevent Chinese EFL teachers from putting their stated beliefs into their actual teaching practice?

\section{Research design and methodology}

A qualitative case study design was deemed the most appropriate for the inquiry of the present study. Case study design is best suited for a bounded system, such as the as the professional development program, which was conducted over a set period of time with a unique group of teachers. This allows exploration of a problem or issue, to provide a detailed description and interpretation of data under investigation, focusing on the participants' perspectives (Creswell 2007). In particular, investigations which involve the design of programs are regarded as common phenomena in case study research (Stake, 1995). This common characteristic was shared by the present study, as an exploration conducted on the basis of a training and teaching program designed by the first author. Moreover, rich descriptions were obtained from participants' actual teaching experience, which served to explicate the three research questions. A case study design thus useful because it enables participants to answer 'how' and 'why' questions focusing on phenomena in a real life setting (Yin 2003). The paper reports part of a larger study, which collected data from pre- and post-workshop observations, face-to-face interviews with teachers and students, and analysis of students' writing products. For the purpose of this paper we draw on teacher interviews, complemented by classroom observation data.

\section{Research setting and participants}

The investigation was undertaken at a university in China by the first author. The purposeful sampling (Patton 2002) strategy was applied to select teachers who could provide sufficiently rich information. Essential criteria for the study were that teachers must be teaching the second year of CE (as this was when writing was more often included in the curriculum); teachers must have at least five years 
teaching experience (to obtain valuable and rich information about pedagogical perceptions); and teachers must have Masters' degree majoring in linguistics or teaching methodology, and actively researching in these areas. Six out of $25 \mathrm{CE}$ teachers who met the criteria were invited to participate although all CE teachers were welcomed to attend the workshops. Details of teachers' background information are outlined in Table 1 below.

Table 1. Teacher participants' background information

\begin{tabular}{|l|l|l|l|l|l|l|}
\hline $\begin{array}{l}\text { Pseudonyms } \\
\text { (gender) }\end{array}$ & $\begin{array}{l}\text { Amy } \\
\text { (Female) }\end{array}$ & $\begin{array}{l}\text { Cathy } \\
\text { (Female) }\end{array}$ & $\begin{array}{l}\text { Jane } \\
\text { (Female) }\end{array}$ & $\begin{array}{l}\text { Kate } \\
\text { (Female) }\end{array}$ & $\begin{array}{l}\text { Mike } \\
\text { (Male) }\end{array}$ & $\begin{array}{l}\text { Patty } \\
\text { (Female) }\end{array}$ \\
\hline Age & 42 & 32 & 36 & 32 & 34 & 42 \\
\hline $\begin{array}{l}\text { Teaching } \\
\text { experience }\end{array}$ & 20 years & 7 years & 12 years & 10 years & 11 years & 20 years \\
\hline $\begin{array}{l}\text { Study level } \\
\text { \& major }\end{array}$ & $\begin{array}{l}\text { Master } \\
\text { Teaching } \\
\text { methods }\end{array}$ & $\begin{array}{l}\text { Master } \\
\text { Linguistics }\end{array}$ & $\begin{array}{l}\text { Master } \\
\text { Linguistics }\end{array}$ & $\begin{array}{l}\text { Master } \\
\text { Linguistics }\end{array}$ & $\begin{array}{l}\text { Master } \\
\text { Applied } \\
\text { Linguistics }\end{array}$ & Master Linguistics \\
\hline Rank & Lecturer & Lecturer & Lecturer & Lecturer & Lecturer & Lecturer \\
\hline Research area & $\begin{array}{l}\text { Teaching } \\
\text { methods, } \\
\text { curriculum }\end{array}$ & $\begin{array}{l}\text { Linguistics, } \\
\text { teaching } \\
\text { methods }\end{array}$ & $\begin{array}{l}\text { Teaching } \\
\text { methods }\end{array}$ & $\begin{array}{l}\text { Linguistics, } \\
\text { teaching } \\
\text { methods }\end{array}$ & $\begin{array}{l}\text { Discourse } \\
\text { analysis }\end{array}$ & $\begin{array}{l}\text { Linguistics, } \\
\text { teaching methods }\end{array}$ \\
\hline $\begin{array}{l}\text { International } \\
\text { experience }\end{array}$ & No & No & No & No & No & $\begin{array}{l}\text { One-month stay in } \\
\text { the USA with a } \\
\text { group of students } \\
\text { on study tour }\end{array}$ \\
\hline
\end{tabular}

\section{Ethical issues}

The study met all ethical requirements of the institution and those of the research setting in China. Written consent was given by each participant after full explanation of the objectives, the procedures of the research and their withdrawal rights. Participant confidentiality was assured through the use of pseudonyms and the removal of any other identifying information.

\section{Workshop design}

Two workshops were designed with two aims: to introduce teachers to the theoretical concepts of the SFL genre approach and its pedagogical model; and to allow the teachers to apply this knowledge to jointly negotiate the final instructional plans based on the initial design. Educational reforms often rely on teachers' professional development in instruction (Sykes, 1996). However, the relationships between changes in teacher knowledge and teaching practice are the critical features of teachers' professional development (Desimone, 2009). To examine the efficacy of SFL genre pedagogy as an effective support for achieving the CECR reform goal thus requires teachers to engage with and apply this pedagogy to their practice. Both workshops were informed by socio- 
cultural theories and the concept of scaffolding in particular. Each workshop lasted three hours to accommodate teachers' busy working schedule.

The first workshop introduced key concepts of SFL genre theories. Teachers were encouraged to make connections to their own pedagogical experiences in a series of interactive discussions on the notions of scaffolding, zone of proximal development and mediation in the genre approach, and their pedagogical values in supporting students' learning development. This was followed by teachers identifying and highlighting from their own experiences, examples of those frequently used interactional scaffolding strategies (e.g. repetition, confirmation and so forth).

The second workshop introduced the pedagogical model of the SFL genre approach and how it informed teaching of the Discussion Genre. Callaghan and Rothery's (1988) three-stage implementation model guided the overall instructional design. In the Modelling stage, a Discussion Genre text was deconstructed and teachers were explicitly introduced to its social purpose and how this purpose was achieved through the schematic structure and linguistic features (Martin and Rose 2005). It was emphasized that the Discussion Genre functions to present information and to argue for both sides of a topical issue, concluding with the writer's view based on evidence (Callaghan and Rothery 1988, Derewianka and Jones 2012). To model the second stage, teachers role-played a classroom situation and collaboratively constructed a Discussion Genre text. Those in the teacher role provided immediate feedback on "students" contributions using different interactional scaffolding strategies. These strategies were then recalled for analysis to consolidate teachers' understandings. Finally, the teachers and the researcher (first author) worked jointly on the researcher's instructional design and decided the final plan for their subsequent teaching practice. This aimed to help teachers consolidate their emergent understandings of the theoretical concepts, the pedagogical model of the SFL genre approach, and its instructional application in particular. Eventually, eight activities were chosen for deconstruction.

\section{Data collection and analysis}

Classroom observation and interview data was collected after the workshops and all processes were audio-recorded. Observations focused on classroom activities for the potential links between participants' self-reported teaching methodologies and the methodologies actually used in teaching (Glesne 2006). A protocol was designed (Creswell 2007) in advance to guide the researcher in focused and organised note-taking throughout the observations. The role of the researcher was a nonparticipatory observer with a passive presence in direct observation (Yin 2003). Immediately after the observation, a 30-minute semi-structured interview (DiCicco-Bloom and Crabtree 2006) was 
conducted with individual teachers to obtain in-depth information about teachers' beliefs about SFL genre pedagogy. Participants were given the option to choose their preferred language (English/Chinese or combined) to eliminate any obstacles arising from language use. All recorded interviews and observations were transcribed and any transcriptions in Chinese were then translated into English by the first author, who speaks Chinese as her first language and is a qualified English teacher. Analytical tools included thematic analysis (Braun and Clarke 2006) of the transcriptions through coding and categorizing, whereupon links between data, and the themes regarding TC and teachers' scaffolding strategies emerged. Borg's (2003) concept was especially useful to frame the overarching relationship between TC of writing instruction and associated factors while Shulman's (1987) model of knowledge base was applied for insight into teachers' knowledge categories. To examine Chinese teachers' use of interactional scaffolding strategies, Hammond and Gibbon's (2005) notion was employed.

\section{Interview findings}

Language teachers' cognition about instruction is closely related to their beliefs regarding language teaching and learning (Borg 2003). To implement SFL genre pedagogy requires teachers' knowledge of the target genre and the pedagogy of guiding students in the teaching-learning cycle.

\section{Stated beliefs about the Modelling stage and adaptation needs}

During interviews, teachers demonstrated a range of beliefs about the value of the Modelling stage as outlined in Table 2. They tended to focus on the benefits of how it worked for learning the format of a Discussion Genre text, while the social communication purpose of text construction was not mentioned. Mike's comment exemplifies this:

What I introduced before may be too general. Text structures always include Introduction, Body and Conclusion regardless of the differences between various text types. Regarding the language features, only some cohesive expressions are provided to them...modelling makes the concept of schematic structure very clear. There's the need of normative model texts or templates for students to imitate.

Mike's previous instructions focused on three general stages of Introduction, Body and Conclusion, some preliminary understanding of the features of schematic structure (Callaghan and Knapp 1989). He also highlighted learning writing by imitating and the important role of text forms in his subject matter content knowledge. His belief mirrored the product approach, which is primarily concerned with the proper forms of the final products (Silva 1990). Mike, however, did not mention how schematic structure worked in relation to the social purpose.

Table 2. Stated values and suggestions/concerns. 


\begin{tabular}{|c|c|c|}
\hline Stages & Values in & Suggestions/Concerns \\
\hline Modelling & $\begin{array}{ll}- & \text { imitating purpose } \\
- & \text { learning } \\
\text { text content } \\
\text { text forms } \\
\text { language features } \\
\text { structure at overall text, paragraph and } \\
\text { sentence levels }\end{array}$ & $\begin{array}{ll}- & \text { selecting models from text-books } \\
- & \text { CET purpose } \\
- & \text { integrating reading } \\
- & \text { more model texts }\end{array}$ \\
\hline $\begin{array}{l}\text { Joint } \\
\text { construction }\end{array}$ & $\begin{array}{l}\text { - enhancing thoughts and developing } \\
\text { argument ideas }\end{array}$ & $\begin{array}{ll}\text { - } & \text { students' participation level } \\
\text { - } & \text { teachers' provision of immediate } \\
& \text { feedback } \\
\text { - } & \text { class size }\end{array}$ \\
\hline
\end{tabular}

Very similar information came from the other teachers. Patty stated: 'for them, Argumentation is Argumentation... When using the term Discussion Genre to talk about what this type of texts are written for, they may feel confused'. Patty believed it was unnecessary to explicitly explain the social purpose of text construction. This belief is contrary to a major principle in SFL genre pedagogy whereby both the knowledge being taught, and the expectations of teaching in the instruction model, should be made explicit (Martin 1999). In Patty's subject matter content knowledge, producing texts of Discussion Genre and Argumentation was misunderstood as having the same social purpose. She had not adopted what was emphasized in training: the Discussion Genre focuses on the arguments from both sides of a topic issue, while Argumentation aims to support only one viewpoint (Derewianka 1990).

Teachers particularly perceived the benefits of deconstruction with regard to the text structure and the specific language features. Kate explained:

First of all, it makes the structure very clear.... what is needed at the beginning of the text...need to state the issue, which is normally in the last sentence of the first paragraph. After that, they should analyse merits [of the issue]. [The guidance of] how to write merits was very specific...they learnt the importance of having elaboration.

For Kate, students were guided to develop their understanding in producing a Discussion Genre text: from the schematic structure to the language features, including both the content and format of text construction; the overall text structure, and also the structures at paragraph and sentence levels. Kate also valued Modelling in developing students' field knowledge, although similarly, she had not yet recognized the social purpose. 
Jane echoed Kate's view: 'model text is a tool which can be used to explain all those aspects of textual features'. This was in line with the key purpose of Modelling in developing students' understanding of the textual features of the target genre.

It was, therefore, obvious that teachers were supportive of modelling, but for different reasons. Mike's emphasis on the accuracy of text form seemed to be shared by most of the teachers. Such difference demonstrated that teachers involved in the same professional training varied from each other in their acceptances of pedagogical changes (Almarza 1996). Apart from the benefits, teachers perceived adaptation needs according to their particular contextual factors and implementation experience. These ideas can be subsumed into teachers' knowledge of curriculum, pedagogy and students (Shulman 1987) although sometimes went across more than one category.

The theme involving teachers' knowledge of curriculum consisted of three components: textbook-based teaching, consideration of the CET requirements, and close integration with teaching reading. Jane, for example, recommended using the CE textbook as a source to teach writing:

I've already adapted the instructional design into another class ...I selected a text in the textbook and I designed similar questions for this model text...the text is directly related to the articles in CETs. I feel it's more effective and has left students with a more profound impression.

Jane valued the benefits of selecting modelling texts from the CE textbook to teach CET writing tasks based on her knowledge of the students, assessment and pedagogy. Her voluntary adaptation of the pedagogy mirrored her strong belief in its value and her open-minded attitude to pedagogical changes.

Likewise, teachers suggested that teaching reading should be integrated with teaching writing. Patty explained: 'if the discussions take place before students have done any reading, before the students have received any "input" [from reading], how can they generate "output". Her emphasis on the reading importance supported the principle of the genre pedagogy, that text reading is frequently used to build up students' field knowledge (Derewianka and Jones 2012).

In teachers' pedagogical knowledge, deconstructing more model texts was an effective strategy when teaching writing. In Jane's knowledge, applying more models could further improve the effectiveness of modelling, as revealed in the interview: 'a model text is a tool...Maybe more model texts can be prepared'. This suggestion supports Humphrey and Macnaught's (2011) recommendation of using two examples of the target genre. The first one allows the teachers to pull apart the text, and to explicitly explain the use of linguistic patterns for specific social purposes while the second one can be used for students' own analysis to develop their understanding. 
Teachers' knowledge of students was also evidenced in their adaptation thoughts. Mike stated: 'questions designed for reading material which is only one-hundred words long is too simple for them'. In contrast, Kate preferred to reduce the length of the reading material: 'I'll choose a shorter text as a model to deconstruct... or maybe extend the teaching time a little bit'. Mike and Kate's different opinions were similarly framed by their knowledge of students. Full consideration of students' variabilities was helpful to guarantee the benefits of SFL genre pedagogy because 'what may be effective in one classroom with one group of students may not be so with another' (Freeman and Johnson 1998, p. 402).

\section{Stated beliefs about the stage of Joint Negotiation of Text}

Opportunities to develop ideas through interaction activities is believed to be a major benefit of Joint Negotiation of Text. Amy explained: 'every student has various thoughts; they can enhance their own thoughts by constructing jointly [which helps them to] consider an issue comprehensively'. Likewise, Patty stressed: 'students can exchange their information here...discuss whether some certain information is important or not. Finally, they can make their decisions on how to make a better elaboration'. As illustrated, the core of these teachers' reflections is that students can develop their understanding of the topic by sharing knowledge. Additionally, it seemed that teachers preferred students to collaboratively construct texts rather than working together with them, thus taking on a position of observer rather than co-collaborator.

However, concerns were raised about organising students for joint construction writing activities. Firstly, students' participation level was believed to greatly influence the effectiveness of joint construction. Mike commented: 'students' co-operation is the key of success in this stage. If [students] can participate actively, this stage must be very helpful'. He considered students' participation as a pre-requisite for achieving successful implementation of this stage. Cathy suggested a way to address the problem: 'when I realize someone is really passive in group work, I'll ask him/her to present'. In essence, success of this stage is largely dependent on students' engagement levels.

Teachers' immediate supervision and feedback was another factor. Cathy emphasized: 'as soon as finishing writing in groups, we must provide them with feedback, a response straight away. In this way, they may be conscious of the mistakes directly'. Cathy's pedagogical knowledge included offering students immediate feedback, which was essential to guarantee success at this stage.

Teachers were also concerned about the contextual factor of class size. Jane highlighted: 'the outcome must be better if it's a class of about 30 students'. Her view about class size aligns with other 
researchers' arguments (Siemon 2010, Yü 2001), that large class size is a barrier to adopting the learner-centred teaching mode inherent to the CLT approach because essential student communication opportunities are reduced.

\section{Stated beliefs about the stage of Independent Construction of Text}

Building on the first two stages of Modelling and Joint Negotiation, the interviews probed teachers' confidence in their students' ability to write independently. Mike highly valued the first two stages in developing students' knowledge:

Students are guided in a process of analysis themselves instead of being told directly about what the result of the article should be like...this way can make them have deep impressions...they themselves can write on their own confidently... they only need to spend time on the specific points. They needn't consider the structure issues as they've been familiarized.

Mike was confident that students would eventually become familiar with the content and contextual features of the target genre, and be able to complete their writing individually.

\section{Observation findings of teachers' actual practices}

What teachers believe strongly influences their classroom practices (Richardson 1996). However, in the present study, what teachers actually did in classroom teaching was not fully congruent with their stated strong beliefs in SFL genre pedagogy. This is particularly evident in to what extent the teachers followed the instructional plan and teachers' performance of designed interaction activities. This section draws on classroom observation data.

\section{Variations in implementation}

The different degrees of implementation could be summarized as full realization, partial realization, and total removal.

Kate and Mike fully realized this stage and their students collaboratively constructed a text, Online Entertainment, which was followed by teachers' immediate feedback. Kate organized students to construct the text in groups. Group ideas were then shared with the whole class and accompanied by Kate's immediate support. In comparison, Mike chose to jointly construct with the whole class. He played the role of an advisor and editor (Feez 1999) to modify students' writing ideas. Kate and Mike's teaching practices consistently reflected scaffolding students through constructive feedback.

In contrast, Cathy and Patty's applications were partially realized. Cathy arranged a group discussion, but there was no session to report back students' discussion results. Patty delivered this stage in an even simpler way with just a few points of a Discussion Genre text: 'to state the issue first, 
and secondly, we need to provide arguments for both sides' and actually skipped the stage of collaborative work. Interestingly, Cathy and Patty's attitudes were not much different from Amy and Jane's where total removal of the stage and positive statements were not evidenced.

Teachers' lack of attention on this stage may be related to their perceptions of the interactions, because learning in this cycle is through guidance and interaction in the context of shared experience to access information related to the topic (Derewianka 2003).

\section{Performance of designed interaction activities}

The teachers were expected to follow the pre-designed interaction tasks to encourage student engagement, with teachers' constant evaluation and guidance, as teachers' talk and interactions enable students to learn from these activities (Mercer 1995). Classroom interaction can be represented as teacher-student (T-S, teacher seeks answers from individual students), teacher-students (T-Ss, teacher talks with the whole class) and student-student (S-S, group and pair work) interactions. Various interaction activities should be balanced based on the purposes of each task or activity (Hammond and Gibbons 2005). Of the eight pre-designed activities (exercises, Exchange) in this study, all were S-S (Exchange 2-5, 8) and T-Ss (Exchange 6-7) interaction activities, except for Ex.1 (individual reading).

\section{Implementing the interactional scaffolding strategies}

Most teachers made efforts for, and achieved some success in applying the interactional scaffolding strategies. Statistically, all teachers invited students to engage in T-S interactions (Amy-6, Cathy-14, Jane-17, Kate-25, Mike-14, and Patty-2). However, Amy and Patty's invitations were significantly lower. Similar disparities are noted in teachers' adoption of interactional scaffolding strategies in classroom discourse is illustrated in Table 3.

Table 3. Identified interactional features in classroom discourse.

\begin{tabular}{|c|c|c|c|c|c|c|c|}
\hline \multirow{2}{*}{$\begin{array}{l}\text { Interactional } \\
\text { scaffolding features }\end{array}$} & \multicolumn{6}{|c|}{$\begin{array}{l}\text { Identified interactional features } \\
\text { in post- workshop classroom discourse }\end{array}$} & \multirow[b]{2}{*}{4} \\
\hline & 1 & 1 & 0 & 1 & 1 & 0 & \\
\hline Elicit & 9 & 10 & 9 & 23 & 11 & 2 & 64 \\
\hline Recap & 5 & 2 & 1 & 1 & 0 & 1 & 10 \\
\hline Recast & 1 & 4 & 8 & 12 & 8 & 0 & 33 \\
\hline Rejection & 0 & 0 & 0 & 0 & 0 & 0 & 0 \\
\hline Repetition & 2 & 9 & 10 & 14 & 2 & 11 & 48 \\
\hline Confirmation & 3 & 15 & 15 & 30 & 8 & 4 & 86 \\
\hline Total & 21 & 41 & 43 & 81 & 30 & 18 & 234 \\
\hline Teachers & Amy & Cathy & Jane & Kate & Mike & Patty & All \\
\hline
\end{tabular}


Teachers most frequently used the interactional scaffolding strategies of elicitation, recast, repetition and confirmation (Hammond and Gibbons 2005, Mercer 1995), while other strategies were rarely used. This may indicate that teachers had a strong knowledge of, and confidence in, using these four strategies. They were also possibly accepted as the most useful.

Meanwhile, there is some evidence showing teachers' success in supporting students in T-S interactions through appropriately using interactional scaffolding strategies. Excerpt 1 evidenced Mike's success.

Excerpt 1 [Q1 \& Q2, Exchange 3] (Mike talked with the fourth student, S4 and fifth student, S5)

1 Mike: S4, how, in what way does the writer state the issue?

S4: $\quad \ldots$

2 Mike: Ok, first, in which paragraph...the writer states the issue?

S4: $\quad$ First.

3 Mike: Ok, first paragraph. So how? Firstly state the general phenomenon concerning about...Now the second question.

S5: $\quad$ Discussion?

4 Mike: Yes, the Discussion is divided up into how many parts?... One, ...

S5: $\quad$ Online Shopping phenomenon.

5 Mike: First is to state the issue. Then?

S5: $\quad$ Discuss the advantages and disadvantages of Online Shopping.

At the beginning, S4 could not answer Mike's question. Mike then narrowed down the scope to adjust the task challenge in the second exchange and suggested 'in which paragraph'. In Exchange 3, Mike confirmed S4's response of 'first' as feedback, then further elicited with 'so how'. In the next exchange, Mike provided a hint, 'one...' to encourage silent S5. As S5's answer was incorrect, in Exchange 5 Mike provided with the answer: 'first is to state the issue', and clue ('Then?') for the next question. With his support, S5 finally responded correctly. Mike's efforts for involving his students' engagement indicated his belief in the functions of interactions and interactional scaffolding strategies in helping students' language learning. His teaching practice aligned with his positive statement regarding joint negotiation stage, which might reflect his open-minded attitude to the pedagogy.

\section{Challenges for offering sufficient help during interactions}

Offering students sufficient help during the interactions appeared to be challenging for some teachers, which may result in teachers' inactivity in interacting with students. Excerpt 2 illustrates the difficulties Amy encountered. 


\section{Excerpt 2 [Q1, Exchange 3]}

1 Amy: What is the issue? How to state the issue? S4?

S4: $\quad$...

2 Amy: Yes, you may pick up some sentences.

S4: 'There are a series of merits for this kind of shopping'. To give examples of advantages and disadvantages.

3 Amy: To list the 'advantages' and 'disadvantages' is to answer this question. What issue are you going to talk about... in general, what kind of question is it about?

S4 It's about the advantages and disadvantages of internet.

4 Amy: The advantages and disadvantages of shopping online. We just talked about 'Discussion Genre'. What should we do in the first part?

S4: $\quad$ General statement...

5 Amy: What to state generally?

S4: $\quad$ For example to present the topic by starting 'with the development of internet'...

6 Amy: You mean to present the topic in the first part?

S4: $\quad$ To present the topic in the first part.

7 Amy: Actually this question asks you: 'How does the writer state the issue?' Could you pick up some sentences?

S4: $\quad$ The first sentence... the first paragraph.

8 Amy: The whole paragraph?

S4: Yes.

9 Amy: Any different ideas? He thinks the whole first paragraph was used to present the topic...To be more specific...S5, Can you locate a specific sentence?

S5: $\quad$ Haven't found it yet.

10 Amy: Haven't found out? Who has found it? ...S6 please?

S6: $\quad$...

Amy tried to elicit the answer for the question 'how does the writer state the issue' based on students' group discussion. When no response was drawn from S4, Amy explicitly provided a clue in Exchange 2 by saying 'you may pick up some sentences'. As S4 misunderstood the question, in Exchange 3, Amy tried to pull S4 back by giving feedback on S4's response and recasting the question. In the next three exchanges, Amy used different questions to guide S4. Unfortunately, S4 still did not understand the question. In Exchange 7, Amy repeated the original question and asked S4 to 'pick up some sentences' - which actually repeated the first two exchanges. However, S4 failed to provide the proper answer. Finally, Amy sought the answer from S5 and S6, but neither was successful.

Failure to elicit the expected response demonstrated Amy's difficulties in giving students immediate support. Mercer $(1995$, p. 26) suggests that teachers use classroom talk to elicit knowledge from students, and if no correct answer is provided, will typically ask another student for the answer. The teacher may try to provide 'strong visual clues and verbal hints' to draw the expected answer and to avoid 'great pains' in telling the answer. Although Amy used different questions to guide students' knowledge construction, her unsuccessful outcome might indicate a need for more training in genre 
pedagogy and associated scaffolding strategies. It may also explain her lack of engagement (also Patty's) in applying T-S interaction activities.

\section{Lack engagement in applying $S$-S interaction activities}

While teachers appeared to have most frequently taken up T-S interaction, there was a lack in applying S-S interaction activities. Teachers largely modified the instructional design, resulting in the removal of a number of interaction activities from the modelling and joint construction stages - the stages considered as 'central to writing development' in the teaching-learning cycle (Humphrey and Macnaught 2011). For example, although students were assigned tasks for pair/group work (Exchange 2 and 4), Amy gave the answers directly without asking for students' output. Likewise, Mike skipped Exchange 2 and only offered an explanation for the first question. The group work in Exchange 4 and 5 was replaced by the teacher's provision of a direct answer.

While the traditional T-S classroom interactions can be very effective in supporting students' language development, Gibbons (2002) also suggests the necessity of creating more varied interaction patterns. She supports McGroarty (1993) who highlights the advantages of group work over other interaction styles for ESL/EFL learners, as it increases opportunities for language use in specific contexts for particular social purposes. Therefore, by removing much of designed S-S interaction activities, the teachers also removed opportunities for students' language development. Thus, classroom teaching tended to remain in teacher-centred.

\section{Conclusion}

From the findings it is evident that the teacher participants built up their knowledge of genre theories through professional development training in the SFL genre approach. All teachers highly valued the SFL genre pedagogy in supporting students' learning of writing. Significant changes occurred in teachers' curricula knowledge, subject matter content knowledge and pedagogical content knowledge, despite the relatively short duration of the training. However, the findings also highlighted that teachers' expressed strong beliefs were not really consistent with what they actually did in their teaching practice, similar to Chaaban's findings (2017).

Several factors may have prevented Chinese EFL teachers from putting their stated beliefs into their actual teaching practice. As the product approach is firmly ingrained in teachers' pre-existing pedagogical knowledge, this is likely to have hindered their implementation of the genre pedagogy. This is reflected in their emphasis on achieving textual forms and grammatical accuracy as the most important criterion to judge the value of this pedagogy. This finding supports Borg's (2006) argument that teaching methods are related to teachers' existing beliefs and practices, but also that the impact of 
workshop training is of great value to teacher professional development to effect change (Chaaban 2017).

Shulman (1987) argues that teachers' own pedagogical knowledge is a factor in how effectively their content knowledge can be understood by students. Similarly, teachers' self-perceptions of subject matter content knowledge influence their views and representation in teaching activities (Borg 2001). In this study, both issues appeared to have contributed to a lack of confidence when implementing new strategies, influencing decisions made. Teachers' attitude to applying pedagogical change is also a key element to achieving CLT. Positive attitude and open-mindedness are important characteristics of teachers, as contextual mediators and moderators (Desimone 2009) in professional development.

Meanwhile, a few contextual factors strongly influenced teachers' full realization of the benefits of the SFL genre pedagogy. The general situation of large class sizes was a hindrance in applying the pedagogical change as this is less conducive to engaging students effectively in interaction activities, similar to the issue raised in Zheng and Borg's study (2014). In addition, teachers' knowledge of students, such as students' language proficiency, directly impacted teachers' choice of instruction. Lastly, the test-driven teaching situation and the ineffective design of the CET writing tasks in combination constrain the extent to which teachers can employ more collaborative and communicative activities, with no substantial changes to the CET writing tasks in response to the CECR reforms of 2004. Thus, we concur with Torrance (1996) that real change is only possible when significant changes in assessment occur.

The issues identified demonstrate that pedagogical change requires time and effort (Guskey 2002) and successful professional development is a process rather than an event (Loucks-Horsley et al. 1998). Introducing SFL genre pedagogy, a new writing approach, in the context of Chinese EFL teaching requires 'systematic effort' (Guskey 2002 p. 383). Time is needed to increase teachers' knowledge about the pedagogy, for implementing it into teaching practice, and eventually for changing pedagogical beliefs encouraged by improved student outcomes. Additionally, it is worth mentioning that apart from a training program, the process of achieving professional development is complex and often impacted by other influences, such as reflection on practice, changes in student outcomes, and motivation (Guskey, 2002), or macro conditions like educational systems, policy environments and school culture, and mediations like sharing ideas (Avalos, 2011). Therefore, professional development must be seen as a journey that involves effort over a period of time for practices to change, with the full consideration of all the influences that work together to achieve these goals. The findings are valuable for those implementing SFL genre pedagogy in an EFL context; for 
introducing educational changes (with adequate time and ongoing support for teacher training and implementation strategies); and for designing teacher education programs (which consider teachers' preexisting knowledge and beliefs). While limitations of this study are the relatively short classroom observations (one 90-minute sessions), and the very limited time assigned to teach CE writing in the research setting, nevertheless change was evident. However, even in the very limited time that the SFL genre approach was taught, the present study demonstrates positive change did occur in teachers' beliefs and classroom practice. This bodes well for working towards achieving national curriculum goals, providing adequate time is given for training and practice.

The changes experienced by teachers in the present study highlighted the value of professional training to enhance teachers' cognition and teaching practice. With carefully designed professional development programmes teachers' beliefs and teaching practice can be impacted positively, taking into consideration that time is needed for changes in practice to develop and that many other influencing factors contribute to such change.

\section{References}

Almarza, G., 1996. Student foreign language teachers' growth. In: D. Freeman and J.C. Richards, ed. Teacher learning in language teaching. Cambridge: Cambridge University Press, 50-78.

Avalos, B., 2011. Teacher professional development in Teaching and Teacher Education over ten years. Teaching and Teacher Education, 27, 10-20. doi:0.1016/j.tate.2010.08.007

Bei, F., 2015. Becoming a better teacher in the writing class: a case study of a writing tutor in a university in China. English language teacher education and development (ELTED) journal, 18(Autumn), 8-19.

Borg, M., 2001. Teachers' beliefs. ELT Journal, 55(2), 186-187.

Borg, S., 2003. Teacher cognition in language teaching: a review of research on what language teachers think, know, believe, and do. Language teaching, 36(2), 81-109.

Borg, S., 2006. Teacher cognition and language education: research and practice. London: Continuum.

Borko, H. (2004). Professional development and teacher learning: mapping the terrain. Educational Researcher, 33(8), 3-15.

Braun, V. and Clarke, V., 2006. Using thematic analysis in psychology. Qualitative research in psychology, 3, 77-101. Burns, A., 2001. Genre-based approaches to writing and beginning adult ESL learners. In: C.N. Candlin and N. Mercer, ed. English language teaching in its social context. New York: Routledge, 200-20.

Cai, C., 2008. On improving students' communicative competence by group interaction. Sino-US English teaching, 5(12), 23-25.

Callaghan, M., and Knapp, P., 1989. The discussion genre. Sydney: Metropolitan East DSP (Language and Social Power Project).

Callaghan, M., and Rothery, J., 1988. Teaching factual writing: a genre based approach. Sydney, N.S.W.: Metropolitan East Region.

Chaaban, Y., 2017. Examining changes in beliefs and practices: English language teachers' participation in the School-based Support Program. Professional development in education, 43(4), 592-611.

Chaisiri, T., 2010. Implementing a genre pedagogy to the teaching of writing in a university context in Thailand. Language Education in Asia, 1, 181-199. 
Cheng, F., 2008. Scaffolding language, scaffolding writing: a genre approach to teaching narrative writing. Asian EFL Journal, 10(2), 167-191.

Creswell, J.W., 2007. Qualitative inquiry and research design: choosing among five approaches, 2nd ed. Thousand Oaks, CA: Sage.

Deng, L., Chen, Q. and Zhang, Y., 2014. Developing Chinese EFL learners' generic competence: a genrebased \& process genre approach. Berlin: Springer Heidelberg.

Derewianka, B., 1990. Exploring how texts work. Rozelle, N.S.W.: Primary English Association.

Derewianka, B., 2003. Trends and issues in genre-based approaches. RELC journal, 34(2), 133-154.

Derewianka, B. and Jones, P., 2012. Teaching language in context. South Melbourne, Vic.: Oxford University Press.

Desimone, L.M., 2009. Improving impact studies of teachers' professional development: toward better conceptualizations and measures. Educational Researcher, 38(3), 181-199.

DiCicco-Bloom, B. and Crabtree, B.F., 2006. The qualitative research interview. Medical education, 40(4), 314321.

Durksen, T.L., Klassen, R.M., and Daniels, L.M., 2017. Motivation and collaboration: the keys to a developmental framework for techers' professional learning. Teaching and Teacher Education, 67, 5366.

Emilia, E., 2005. A critical genre-based approach to teaching academic writing in a tertiary EFL context in Indonesia. Thesis $(\mathrm{PhD})$. The University of Melbourne.

Fang, F., 2010. A discussion on developing students' communicative competence in College English teaching in China. Journal of language teaching and research, 1(2), 111-116.

Farrell, T.S.C. and Lim, P.C.P., 2005. Conceptions of grammar teaching: a case study of teachers' belief and classroom practices. TESL-EJ, 9(2), 1-13.

Feez, S., 1999. Text-based syllabus design. TESOL in context, 9(1), 11-14.

Freeman, D. and Johnson, K.E., 1998. Reconceptualizing the knowledge-base of language teacher education. Tesol quarterly, 32(3), 397-417.

Fullan, M., 2001. The new meaning of educational change, 3rd ed. New York: Teacher College Press.

Gao, J. and Huang, J., 2010. On communicative competence in curriculum design: a comparison of the College English Curriculum Requirements and the English Curriculum Standards. Polyglossia, 18, 73-86.

Gibbons, P., 2002. Scaffolding language scaffolding learning: teaching second language learners in the mainstream classroom. Portsmouth, NH: Heinemann.

Glesne, C., 2006. Becoming qualitative researchers: an introduction, 3rd ed. Boston, Mass: Pearson Allyn \& Bacon.

Guskey, T.R., 2002. Professional development and teacher change. Teachers and Teaching, 8(3), 381-391.

Hammond, J. and Gibbons, P., 2005. Putting scaffolding to work: the contribution of scaffolding in articulating ESL education. Prospect, 20(1), 6-30.

Hedrick, W.B. Harmon, J.M. and Linerode, P.M. 2004. Teachers' beliefs and practices of vocabulary instruction with social studies texbooks in Grades 4-8. Reading horizons, 45(2), 103-125.

Hu, G., 2007. Developing an EAP writing course for Chinese ESL students. RELC journal, 38(1), 67-86.

Humphrey, S. and Macnaught, L., 2011. Revisiting joint construction in the tertiary context. Australian journal of language and literacy, 34(1), 99-115.

Hyland, K., 2007. Genre pedagogy: language, literacy and L2 writing instruction. Journal of second language writing, 16, 148-164.

Hymes, D., 1972. On coummunicative competence. In: J.B. Pride \& J. Holmes, ed. Sociolinguistics (pp. 269293). Penguin: Harmondsworth.

Jamalzadeh, M. and Shahsavar, Z. 2015. The effects of contextual factors on teacher's beliefs and practices. Procedia - Social and Behavioral Sciences, 192, 166-171.

Kang, Y. and Cheng, X. 2014. Teacher learning in the workplace: a study of the relationship between a novice EFL teacher's classroom practices and cognition development. Language teaching research, 18(2), 169-186.

Khader, F.R., 2012. Teachers' pedagogical beliefs and actual classroom practices in social studies instruction. American international journal of contemporary research, 2(1), 73-90. 
Kim, T., 2006. Writing instruction for English language teachers: teacher beliefs, writing tasks, and method. Thesis (PhD). University of Illinois.

Lin, B., 2006. Genre-based teaching and Vygotskian principles in EFL: the case of a university writing course. Asian EFL Journal, 8 (3), 226-248. Accessed August 23, 2018. https://www.asian-efl-journal.com/1202/quarterly-journal/genre-based-teaching-andwgotskian-principles-in-efl-the-case-of-a-university-writing-course/\#squelch-taas-tabcontent-0-3

Loucks-Horsley, S., Hewson, P.W., Love, N. and Stiles, K. 1998. Designing professional development for teachers of science and mathematics. Thousands Oaks, CA: Corwin Press.

Martin, J.R., 1999. Mentoring semogenesis: 'genre-based' literacy pedagogy. In: C. Frances, ed. Pedagogy and the shaping of consciousness: linguistic and social process. London: Cassell, 123-155

Martin, J.R. andRose, D., 2005. Genre relations: mapping culture. Oakville, CT: Equinox Pub.

McGroarty, M., 1993. Cooperative learning and language acquisition. In: D. Holt ed. Cooperative learning: $a$ response to linguistic and cultural diversity. Washington, DC: Center for Applied Linguistics.

Mercer, N., 1995. The guided construction of knowledge: talk amongst teachers and learners. England: Clevedon, Avon.

Patton, M.Q., 2002. Qualitative evaluation and research methods, 3rd ed. Thousand Oaks, Calif: Sage Publications.

Priestley, M., 2011. Schools, teachers, and curriculum change: a balancing act? J Educ Change, 12, 1-23.

Qian, X., 2010. A balanced approach to the teaching of intermediate-level writing skills to EFL students. English language teaching, 3(2), 13-16.

Richardson, V., 1996. The role of attitudes and beliefs in learning to teach. In: J.P. Sikula, T.J. Buttery and E. Guyton, ed. Handbook of research on teacher education: a project of the Association of Teacher Educators. New York: Macmillian library Reference, 102-119.

Shi, L., Baker, A., \& Chen, H. (2017). Chinese EFL teachers' cognition about the effectiveness of genre pedagogy: a case study. RELC Journal, Online first, 1-19. doi:10.1177/0033688217716506Shulman, L.S., 1987. Knowledge and teaching: foundations of the new reform. Harvard Educational Review, 57(1), 1-21.

Siemon, A., 2010. Learning English in China: is communicative language teaching a reality? Practically primary, $15(2), 39-42$.

Silva, T., 1990. Second language composition instruction: developments, issues, and directions in ESL. In: B. Kroll, ed. Second language writing: research insights for the classroom. Cambridge: Cambridge University Press, 11-23.

Stake, R., 1995. The art of case study research. Thousand Oaks, CA: Sage.

Sykes, G. 1996. Reforms of and as professional development. Phi Delta Kappan, 77(7), 465-489.

Tian, C., 2010. Genre-based approach and the teaching of writing through reading assisted by blackboard learning system. In: 2010 2nd International Conference on Industrial Mechatronics and Automation. Wuhan, China. Accessed August 23, 2018. https://ieeexplore.ieee.org/document/5538389/citations?tabFilter=papers\#citations

Torrance, H., 1996. Series editor's introduction. In: H. Torrance, ed. Education, assessment and society. Buckingham Philadelphia: Open University Press, $x$-xii.

Wang, C., 2013. A study of genre approach in EFL writing. Theory and pracitce in language studies, 3(11), 2128-2135.

Wells, G., 1999. Dialogic inquiry: towards a sociocultural practice and theory of education. MA: Cambridge University Press.

Yang, L. and Gao, S., 2013. Beliefs and practices of Chinese university teachers in EFL writing instruction. Language, Culture and curriculum, 26(2), 128-145.

Yin, R.K., 2003. Case study research: design and methods, 3rd ed. Thousand Oaks, Calif: Sage Publications.

Yü, L., 2001. Communicative language teaching in China: progress and resistance. Tesol Quarterly, 35(1), 194198. 
Zhang, B., 2011. A study on the role of teachers' cognition in foreign language teaching. US-China foreign language, 9(7), 435-442.

Zhang, F. and Liu, Y., 2013. A study of secondary school English teachers' beliefs in the context of curriculum reform in China. Language teaching research, $O(0), 1-18$.

Zheng, X. and Borg, S., 2014. Task-based learning and teaching in China: secondary school teachers' beliefs and practices. Language teaching research, 18(2), 205-221. 